\title{
PERHITUNGAN TINGKAT KESIAPAN IMPLEMENTASI SMART CITY DALAM PERSPEKTIF SMART GOVERNANCE DENGAN METODE FIS MAMDANI
}

\author{
Sri Eniyati ${ }^{1}$, Rina Candra NS $^{2}$, Retnowati ${ }^{3}$, Sri Mulyani ${ }^{4}$, Khristma Martha A.P ${ }^{5}$ \\ 1,2,5Program Studi Teknik Informatika, Fakultas Teknologi Informasi, Universitas Stikubank \\ 3,4Program Studi Manajemen Informatika, Fakultas Teknologi Informasi, Universitas Stikubank \\ e-mail: ${ }^{1}$ eniyati03@gmail.com, ${ }^{2}$ r_candra_ns@edu.unisbank.ac.id, ${ }^{3}$ retnowati @edu.unisbank.ac.id, \\ ${ }^{4}$ srimulyani@edu.unisbank.ac.id, ${ }^{5}$ khrisma.martha@gmail.com
}

\begin{abstract}
Abstrak
Smart City adalah skonsep tata kota yang mengoptimalkan teknologi informasi dan digital untuk meningkatkan kesejahteraan dan kebahagiaan masyarakat, serta meningkatkan layanan Pemerintah. Kota Pekalongan sedang berupaya untuk mempersiapkan diri dalam proses implementasi Smart City. Dalam referensi diketahui bahwa salah satu indikator kesiapan implementasi Smart City adalah Smart Governance, yang terdiri atasi empat indikator utama yaitu Participation in decision-making, public and social services, Transparent Governance, political strategies and perspectives. Dari keempat indikator tersebut diperjelas ke dalam indikator operasional yang lebih mudah diukur secara kuantitatif. Oleh sebab itu metode penelitian dipilih mix research methods karena data yang diperoleh dilakukan melalui cara kualitatif dengan wawancara kepada narasumber. Hasil data dikelola dan diolah menggunakan cara kuantitatif. Cara kuantitatif tersebut adalah metode Fuzzy Inference System (FIS) Mamdani. Dari keempat indikator utama diturunkan menjadi 21 variabel input Hasil yang diperoleh adalah tingkat kesiapan Kota Pekalongan dalam mengimplementasikan Smart City dari Perspektif Smart Governance adalah 1,5 (Sedang).
\end{abstract}

Kata kunci: Smart City, Smart Governance, FIS Mamdani

\section{PENDAHULUAN}

Smart City merupakan suatu konsep yang merupakan suatu tata kota dengan mengoptimalkan teknologi informasi dan digital untuk meningkatkan kesejahteraan dan kebahagiaan masyarakat, serta meningkatkan layanan Pemerintah sehingga dapat mengurangi dan menekan biaya, waktu serta tenaga. Hal ini sejalan dengan berbagai pengertian tentang Smart City yang menekankan bahwa Smart City adalah upaya untuk membahagiakan warganya [1][2][3][4].

Konsep Smart City menjadi impian seluruh dunia dan telah, sedang serta akan diimplementasikan ke seluruh negara yang menghendaki perubahan baik bagi warga negaranya. Berbagai penelitian yang membahas tentang implementasi serta evaluasi Smart City juga telah banyak dilakukan[5][6][7][8]. Sesuai dengan karakteristik Smart City dari berbagai sumber, diketahui bahwa secara umum kriteria Smart City adalah meliputi Smart Economy, Smart People, Smart Mobility, Smart Environment, Smart Living dan Smart Governance [6][1][2][9]. Kriteria- kriteria tersebut bersifat kualitatif, sehingga diperlukan indikator-indikator kuantitatif agar mempermudah analisis keberhasilan suatu kota mengupayakan implementasi Smart City.

Jika dikaitkan antara penerapan Smart City yang terjadi di berbagai negara, maka dapat dijelaskan bahwa secara fakta Indonesia telah menggaungkan Open Government Indonesia (OGI) sejak 2008 serta menerapkan Keterbukaan Informasi Publik (KIP) sejak 2008. Sekalipun demikian, Indonesia belum sepenuhnya seluruh wilayah daerah menerapkan konsep Smart City. Beberapa kota yang diakui telah mengupayakan ke arah Smart City antara lain Jakarta, Surabaya, Bandung, Denpasar dan Yogyakarta. Pekalongan sebagai salah satu kota di wilayah Propinsi Jawa Tengah telah mengimplementasikan e-Government dengan menggunakan Free Open Source untuk aplikasi perangkat lunaknya. Sekalipun demikian upaya ke ranah Smart City belum sepenuhnya dapat dilaksanakan. Persiapan ke arah perspektif Smart City sudah dilakukan. Salah satu buktinya adalah 
keterlibatan masyarakat melalui berbagai unsur kelompok untuk mendukung percepatan proses ke arah optimalisasi Teknologi Informasi[10].

Dalam berbagai penelitian tentang Smart City, beberapa peneliti memanfaatkan metode Fuzzy untuk penerapan Smart City, antara lain [11][12][13][2]. Salah satu penelitian yang menarik perhatian adalah hasil penelitian dari M.I Perangin-Angin, dkk. Dalam penelitiannya[14] keenam variabel Smart City digunakan untuk memprediksi tingkat implementasi Smart City. Metode perhitungan yang digunakan untuk melakukan prediksi adalah Fuzzy Inference System Tsukamoto. Sekalipun demikian, penelitian ini memiliki beberapa aspek yang perlu dikritisi. Pertama tentang variabel yang digunakan. Penelitian ini melakukan prediksi dengan variabel mentah bersifat kualitatif. Variabel tersebut kemudian dikuantitatifkan melalui skor himpunan Fuzzy: Baik, Sedang dan Buruk dengan rentang nilai kurang dari 50 dan lebih dari 79. Sisi yang perlu dikritisi adalah variabel yang digunakan ini tidak memiliki turunan indikator pendukung yang pada akhirnya pengertian dan pengukurannya justru benar- benar menjadi Fuzzy. Smart People, sebagai contoh, tidak bisa hanya sekedar diberikan nilai baik, sedang atau buruk tanpa didukung oleh indikator apa yang membuat suatu kota dikatakan Smart People. Kedua, penelitian ini membuat prediksi dengan menggunakan FIS Tsukamoto yang bersifat sangat umum sehingga berpotensi pada kurang validnya cara menarik kesimpulan, yang disebabkan oleh adanya perbedaan atau ciri khas yang dimiliki oleh setiap kota.

Secara prinsip Fuzzy Inference System (FIS) adalah sebuah metode yang dapat digunakan untuk mengetahui nilai optimal dari sederetan variabel input yang bernilai linguistik (kualitatif). Hal ini sejalan dengan apa yang diungkapkan oleh Kusumadewi, Sri dkk[15]. Terdapat tiga metode FIS, yaitu Tsukamoto, Mamdani dan Sugeno. Inferensi fuzzy tipe Tsukamoto dan Mamdani memberikan output yang merupakan himpunan fuzzy. Sugeno-type

inference memberikan output yang berupa ekspresi matematis konstan atau linear (weighted)[15]. FIS Mamdani akan digunakan dalam penelitian ini sebagai tools untuk melakukan analisa, dengan dukungan software Matlab R2016a. Selain itu, FIS Mamdani juga telah banyak digunakan untuk menyelesaikan berbagai persoalan dalam berbagai penelitian [16][17][18][19][20][21]. Hal ini memperkuat pendapat bahwa FIS Mamdani dapat digunakan sebagai metode untuk menyelesaikan persoalan yang akan diselesaikan dalam penelitian ini.

Berdasarkan hal-hal yang telah dikritisi pada penelitian tentang prediksi pelaksanaan Smart City serta mempertimbangkan komitmen Kota Pekalongan untuk menjadikan kotanya maju dengan potensi implementasi Smart City, maka penelitian ini akan terfokus pada obyek penelitian Pemerintah Kota Pekalongan melalui Dinas Komunikasi dan Informatika (Diskominfo). Adapun persoalan yang hendak diteliti adalah tingkat kesiapan optimal kota untuk menerapkan Smart City. Metode yang dipilih untuk menilai tingkat kesiapan tersebut adalah FIS Mamdani dan hanya terfokus kepada aspek karakteristik Smart Governance.

\section{TINJAUAN PUSTAKA}

\section{a. Pengertian Smart City}

Terdapat berbagai definisi tentang Smart City. Smart City pada dasarnya adalah sebuah kota yang mampu mengelola Kota dengan cara menggabungkan seluruh kekuatan baik dari segi sumber daya manusia, sumber daya alam, infrastruktur dan pemerintah dengan mengoptimalkan Teknologi Informasi, sehingga kota tersebut mampu menjadikan warganya menjadi mandiri, partisipatif, nyaman dan sejahtera.

Hal ini sejalan dengan apa yang telah dinyatakan oleh beberapa peneliti bahwa Smart City adalah Kota yang mampu mengelola segenap Sumber Daya yang dimilikinya untuk meningkatkan kualitas hidup warganya[6][4][9][22][23][2].

Giffinger, dkk menyatakan bahwa Smart City merupakan sebuah kota yang memiliki performa/tampilan baik yang memiliki cara pandan ke depan dari aspek ekonomi, masyarakat, pemerintahan, mobilitas, lingkungan dan kehidupan, semuanya dibangun karena kerja sama yang baik dan ditentukan oleh warganya yang memiliki kemandirian dan kesadaran yang tinggi[6]. Sementara itu Yoshikawa, dkk menyebutkan bahwa Smart City adalah kota yang berusaha untuk mencapai 
kepedulian terhadap lingkungan, serta menjaga aspek kemanan dan kenyamanan melalui pemberdayaan infrastruktur yang mendukung gaya hidup konsumen bersamaan dengan infrastruktur pengelolaan kota yang menghubungkan keduanya menggunakan teknologi informasi [24]. Hal ini senada dengan apa yang dikatakan oleh Cohen dimana Smart City adalah kota yang secara terus menerus memanfaatkan teknologi informasi dan komunikasi agar kehidupan masyarakat menjadi lebih cerdas dan efisien, terutama dalam penggunaan sumber daya, menghemat energi serta biaya dan meningkatkan kualitas hidup ke arah yang lebih baik. Dan ditegaskan pula oleh Cogen bahwa Smart City adalah kota yang terus menerus melakukan pengurangan jejak lingkungan dengan terus berinovasi untuk mengurangi dampak polusi Karbon[25].

Pendefinisian Smart City yang mengaitkannya dengan pemanfaatan TIK juga dinyatakan oleh Meijer, dimana Smart City adalah sebuah kota yang menginvestasikan modal manusia dan sosial serta infrastruktur baik tradisional maupun modern untuk mendorong pertumbuhan ekonomi yang berkelanjutan dan meningkatkan kualitas hidup, melalui pengelolaan sumber daya alam secara bijaksana dan partisipatif[6].

\section{b. Karakteristik dan Indikator Smart City}

Beberapa peneliti menyebutkan bahwa Smart City memiliki karakteristik tertentu, tetapi secara umum Smart City memiliki karakteristik Smart Economy, Smart People, Smart Governance, Smart Mobility, Smart Environment, Smart Living[6][1]. Sedangkan Mosannenzadeh dan Vettorato memiliki sedikit perspektif berbeda tentang karakteristik Smart City, yang terdiri dari Smart Economy, Smart Environment: Smart Natural Environment dan Smart Build Environment, Smart Mobility, Smart Governance, Smart Services, Smart Community [9]. Tetapi dapat diketahui dengan jelas bahwa beberapa sumber penelitian menegaskan bahwa salah satu karakteristik Smart City adalah Smart Governance, yang akan menjadi fokus penting dalam penelitian yang akan dilakukan.

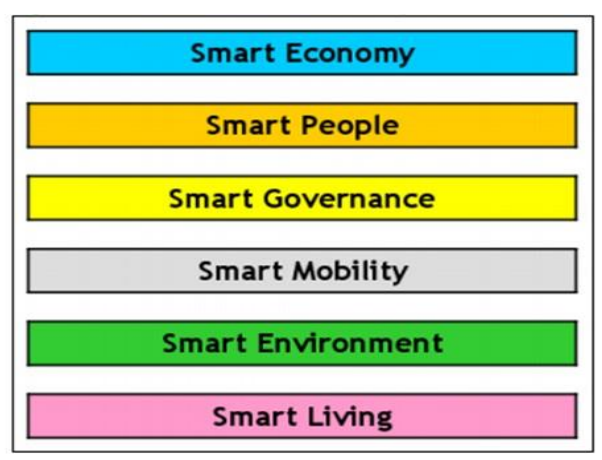

Gambar 1. Karakteristik Smart City Menurut Giffinger, dkk[6]

Christian dan Roscia menambahkan dalam penelitiannya indikator dari setiap karakteristik Smart City, dimana, sebagai contoh Smart Governance memiliki indikator: Participation in decisionmaking, public and social services, Transparent Governance, political strategies and perspectives [1]. Karena fokus utama penelitian ini ada pada karakteristik Smart Governance, maka panduan utama untuk menggali informasi tentang indikator Smart Governance adalah indikator yang dikemukakan oleh Cristian dan Roscia, dengan mengedepankan pada aspek budaya yang berjalan di Kota Pekalongan dan perspektif masing-masing narasumber.

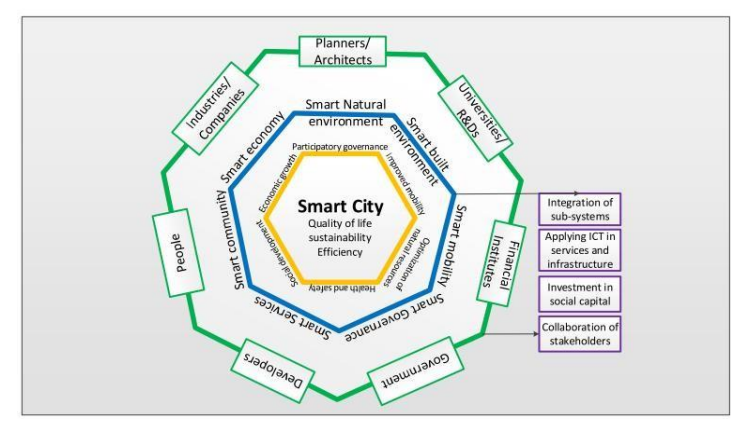


Gambar 2. Karakteristik Smart City Oleh Mosannenzadeh dan Vettorato[9]

Tabel 1. Indikator Smart City Menurut Christian dan Roscia[1]

\begin{tabular}{|c|c|}
\hline KARAKTERISTIKSMART CITY & INDIKATOR SMART CITY \\
\hline \multirow[t]{7}{*}{ Smart Economy } & Innovative Spirit \\
\hline & Entrepreneurship \\
\hline & Economic Image and Trademarks \\
\hline & \begin{tabular}{|l|} 
Productivity \\
\end{tabular} \\
\hline & Flexibility of labor market \\
\hline & International embeddedness \\
\hline & Ability to transform \\
\hline \multirow[t]{4}{*}{ Smart Mobility } & Local accessibiity \\
\hline & (inter)national Accessibility \\
\hline & Availability of ICT-Infrastructure \\
\hline & Sustainable, innovative and safe transport systems \\
\hline \multirow[t]{4}{*}{ Smart Environment } & Attractiveness of natural conditions \\
\hline & \begin{tabular}{|l|} 
Pollution \\
\end{tabular} \\
\hline & environment protection \\
\hline & sustainable resource management \\
\hline \multirow[t]{7}{*}{ Smart People } & Level of qualification \\
\hline & Affinity to lifelong learning \\
\hline & Social and ethnic plurality \\
\hline & Flecibility \\
\hline & Creativity \\
\hline & Cosmopolitanism/Open-mindedness \\
\hline & Participation in public life \\
\hline \multirow[t]{6}{*}{ Smart Living } & Cultural facilities \\
\hline & Health conditions \\
\hline & Individual safety \\
\hline & Housing quality \\
\hline & Education facilities \\
\hline & Touristic attractiveness \\
\hline \multirow[t]{4}{*}{ Smart Governance } & Participation in decision-making \\
\hline & Public and social services \\
\hline & Transparent governance \\
\hline & Political strategies and perspectives \\
\hline
\end{tabular}

Dalam penelitian lain dengan tema Smart City yang dilakukan oleh Perangin-Angin, dkk [14], dapat diketahui bahwa untuk menakar tingkat implementasi Smart City digunakan karakteristik yang sama, yaitu Smart Economy, Smart People, Smart Governance, Smart Mobility, Smart Environment, Smart Living. Sekalipun demikian, masing-masing karakteristik tersebut tidak diturunkan lagi ke dalam indikator-indikator yang bersifat crisps atau linguistik. Setiap karakteristik hanya dibagi ke dalam tiga klasfisikasi linguistik, Baik, Sedang dan Kurang. Sedangkan metode FIS yang digunakan adalah FIS Tsukamoto. Hal inilah yang dijadikan sebagai titik kritis terhadap penelitian sebelumnya yang hendak dipertajam dalam penelitian yang diusulkan. Karena keterbatasan waktu, maka secara khusus akan diambil fokus utama pada aspek karakteristik Smart Governance dengan metode FIS Mamdani.

\section{METODE PENELITIAN}

\section{a. Jenis Penelitian : Mix Research Methods}

Dalam penelitian ini metode penelitian yang digunakan adalah Mix Research Methods. Dalam berbagai buku tentang metodologi penelitian, Mix Research Methods dapat digunakan sebagai solusi ketika penelitian tidak selalu harus menjawab hipotesa tetapi juga perlu mengolah data yang bersifat kuantitatif, di sisi lain tidak selalu data penelitian diperoleh hanya dari wawancara saja[26][27][28]. 
Oleh karena itu, penelitian ini menggunakan metode kualitatif melalui prosedur wawancara untuk menggali informasi dari para stakeholder dalam rangka menentukan indikator-indikator dari variabel input dan output yang akan ditetapkan. Metode ini sekaligus digunakan untuk menjawab tujuan penelitian poin 1. Berdasarkan indikator yang diperoleh secara kualitatif tersebut, maka diperlukan metode kuantitatif yang digunakan untuk menentukan batasan dari setiap indikator, memilih representasi himpunan serta menghitung nilai berdasarkan input yang dimasukkan. Secara kuantitatif, proses ini akan menggunakan Fuzzy Inference Systems (FIS) Mamdani R2016a. Metode Kuantitatif ini digunakan untuk menjawab tujuan penelitian pada poin kedua. Berikut adalah tahap penelitian sesuai dengan Gambar 3.

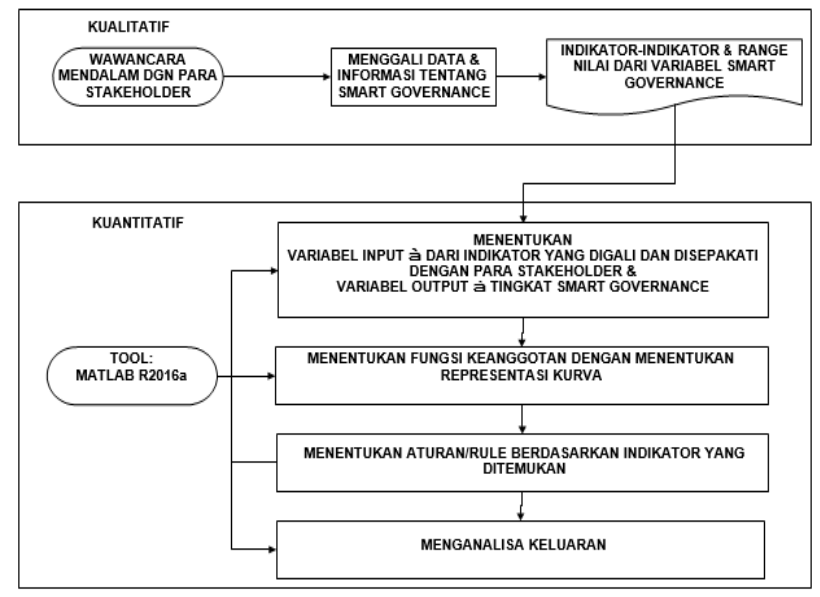

Gambar 3. Tahap-tahap Penelitian

b. Obyek Penelitian

Adapun obyek penelitian ini adalah Pemerintah Kota Pekalongan, dalam hal ini Dinas Komunikasi dan Informasi Kota Pekalongan. Hal ini didasarkan atas pengertian Smart City yang secara jelas memaparkan peran serta TIK dalam pengelolaannya. Di Kota Pekalongan, segala hal yang terkait dengan pengelolaan TIK berada di bawah SKPD Dinas Komunikasi dan Informasi Kota Pekalongan.

c. Populasi dan Sampel

Jumlah stakeholder yang terlibat dalam pengelolaan manajemen di Diskominfo Kota Pekalongan 25 orang. Dua puluh lima orang tersebut merupakan narasumber yang akan digali informasinya menggunakan pendekatan kualitatif melalui wawancara serta observasi.

\section{HASIL DAN PEMBAHASAN}

\section{a. Indikator Smart City Dalam Perspektif Smart Governance}

Dengan kesepakatan bersama antara peneliti dan narasumber, dimana Smart Governance adalah bagian dari Smart City yang didalamnya memuat indikator-indikator. Adapun indikator-indikator tersebut adalah (1) Partisipasi Masyarakat Dalam Pengambilan Keputusan, (2) Ketersediaan Layanan Publik dan Sosial, (3) Transparansi Tata Kelola, (4) Cara Pandang dan Strategi Politik [1]. Berdasarkan keempat indikator tersebut, narasumber memberikan pendapat bahwa masing-masing indikator dijabarkan ke dalam indikator-indikator turunan yang dapat terukur secara kuantitatif.

Adapun Partisipasi Masyarakat Dalam Pengambilan Keputusan diterjemahkan sebagai kemampuan Pemerintah Daerah mengelola dan mengkoordinasi kelompok masyarakat yang mendukung proses pengambilan keputusan. Indikator turunannya adalah jumlah payung hukum yang dihasilkan, dukungan dana yang diberikan, jumlah kelompok yang terorganisir, pelibatan masyarakat dalam forum pengambilan keputusan per tahun.

Indikator Ketersediaan Layanan Publik dan Sosial dipahami sebagai Ketersediaan Pelayanan Publik dan Pengelolaan Pengaduan Masyarakat. Pelayanan Publik terdiri dari indikator turunan ketersediaan pelayanan publik secara online. Sedangkan Pengelolaan Pengaduan Masyarakat 
diperjelas melalui indikator jumlah pengaduan per tahun, jumlah pengaduan terselesaikan per tahun, lama waktu penyelesaian per kasus rata-rata per tahun.

Transparansi Tata Kelola diterjemahkan sebagai ketersediaan grand design (blue print/road map) Pelayanan Publik, Kesediaan Pemerintah Membuka Diri Terhadap Informasi Yang Dibutuhkan Masyarakat, Keterbukaan Rencana Pembangunan dan Kesejahteraan Untuk Masyarakat.

Cara pandang dan strategi politik dinyatakan secara operasional sebagai kemampuan merangkul semua pihak, ketersediaan organ dan struktur tata Pemerintahan dan Politik serta Penanganan dan Antisipasi Konflik Horisontal yang terjadi.

Dari masing-masing indikator yang telah diturunkan kedalam indikator operasional, diperjelas kembali dalam variabel-variabel yang mudah untuk diukur secara kuantitatif seperti tampak pada table 2.

Tabel 2. Indikator dan Turunan Indikator Smart Governance Pemkot Pekalongan

\begin{tabular}{|c|c|c|c|}
\hline NO & INDIKATOR & BREAKDOWN INDIKATOR & VARIABEL \\
\hline \multirow[t]{4}{*}{1} & \multirow{4}{*}{$\begin{array}{l}\text { Partisipasi Masyarakat } \\
\text { Dalam Pengambilan } \\
\text { Keputusan }\end{array}$} & \multirow{4}{*}{$\begin{array}{l}\text { Kemampuan Pemda } \\
\text { mengelola\&Masyarakat Yang } \\
\text { Mendukung Proses Pengambilan } \\
\text { Keputusan }\end{array}$} & Jumlah Payung Hukum Yang Dihasilkan \\
\hline & & & Dukungan Dana Yang Diberikan \\
\hline & & & Jumlah Kelompok Yang Terorganisir \\
\hline & & & $\begin{array}{l}\text { Pelibatan Masyarakat dalam Forum Pengambilan } \\
\text { Keputusan/Th }\end{array}$ \\
\hline \multirow[t]{4}{*}{2} & \multirow{4}{*}{$\begin{array}{l}\text { Pelayanan Publik dan } \\
\text { Sosial }\end{array}$} & Ketersediaan Pelayanan Publik & Online \\
\hline & & \multirow{3}{*}{$\begin{array}{l}\text { Pengelolaan Pengaduan } \\
\text { Masyarakat }\end{array}$} & Jumlah Pengaduan/th \\
\hline & & & Jumlah Pengaduan Terselesaikan/th \\
\hline & & & Lama Waktu Penyelesaian/Kasus rata-rata/th \\
\hline \multirow[t]{7}{*}{3} & \multirow{7}{*}{$\begin{array}{l}\text { Transparansi Tata } \\
\text { Kelola }\end{array}$} & \multirow{5}{*}{$\begin{array}{l}\text { Kepemilikan Grand Design (Blue } \\
\text { Print) / Road Map Pelayanan } \\
\text { Publik }\end{array}$} & Jenis Blue Print/pelayanan publik \\
\hline & & & SOP \\
\hline & & & Payung Hukum Keterbukaan Informasi \\
\hline & & & $\begin{array}{l}\text { Persentase SKPD terbuka terhadap Informasi Utk } \\
\text { Masyarakat }\end{array}$ \\
\hline & & & \begin{tabular}{|l} 
Jenis Media Yang Disediakan Untuk Mengakses \\
Informasi Utk Masyarakat \\
\end{tabular} \\
\hline & & \multirow{2}{*}{$\begin{array}{l}\text { Keterbukaan Rencana Untuk } \\
\text { Masyarakat }\end{array}$} & Jenis Perencanaan \\
\hline & & & Mekanisme Perencanaan \\
\hline \multirow[t]{6}{*}{4} & \multirow{6}{*}{$\begin{array}{l}\text { Cara Pandang dan } \\
\text { Strategi Politik }\end{array}$} & \multirow{4}{*}{$\begin{array}{l}\text { Kemampuan Merangkul Semua } \\
\text { Pihak }\end{array}$} & Organisasi Keagamaan \\
\hline & & & Organisasi Seni dan Kebudayaan \\
\hline & & & Persentase Pertemuan antar organisasi keagamaan/th \\
\hline & & & \begin{tabular}{|l} 
Persentase Aktualisasi Kelompok Seni dan \\
Budaya/th
\end{tabular} \\
\hline & & \begin{tabular}{|l|} 
Ketersediaan organ dan struktur \\
tata pemerintah dan politik \\
\end{tabular} & Kelengkapan Unsur tata kelola sospol \\
\hline & & \begin{tabular}{|l} 
Penanganan dan Antisipasi \\
Konflik horizontal yang terjadi
\end{tabular} & Persentase potensi konflik/th \\
\hline
\end{tabular}

\section{b. Klasifikasi Variabel Input dan Variabel Output Smart Governance}

Berdasarkan indikator yang telah ditentukan seperti tampak pada tabel 4.1, maka ditemukan variabel-variabel input yang menjadi variabel operasional dalam penelitian ini. Berdasarkan wawancara secara terstruktur dengan narasumber maka diperoleh nilai operasional sebagai standar terukur untuk setiap variabel input.

Jika dikaitkan dengan kepentingan pengolahan data menggunakan Fuzzy Inference System Mamdani, maka setiap variabel input harus dikelompokkan sesuai dengan representasi himpunan yang telah dipilih. Dalam penelitian ini, representasi kurva yang dipilih adalah representasi kurva bahu dengan himpunan keanggotaan rendah, sedang dan tinggi. Adapun rentang yang ditentukan adalah 0 sampai dengan 3. Sebagai contoh, diberikan Variabel Input A1, maka A1 memiliki tiga himpunan keanggotaan \{rendah, sedang, tinggi\}. Representasi kurva bahu tampak pada gambar 4. 


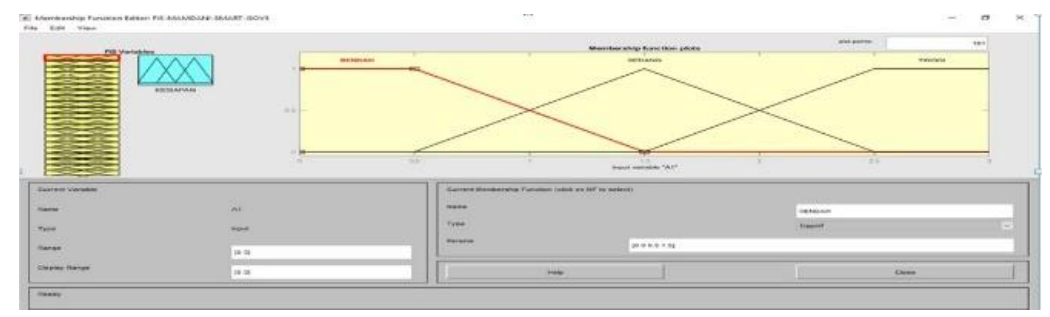

Gambar 4. Representasi Kurva Bahu

Adapun variabel output yang ditetapkan adalah Kesiapan, dengan representasi kurva bahu. Himpunan keanggotaan variabel output kesiapan adalah \{rendah, sedang, tinggi\} dengan rentang nilai antara 0-3. Representasi kurva untuk variabel output Kesiapan dapat dilihat pada gambar 5.

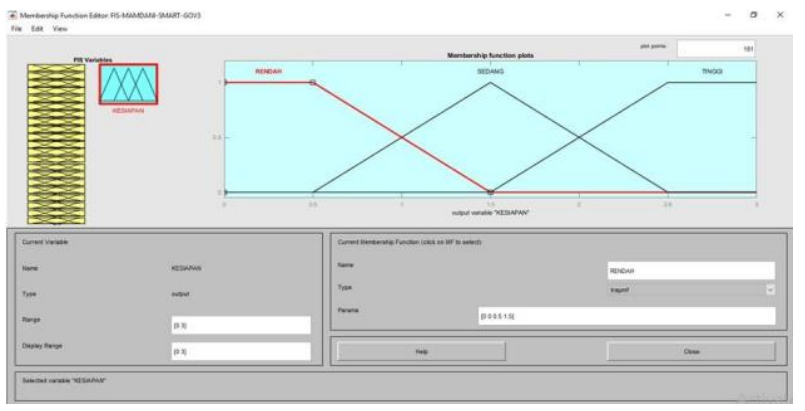

Gambar 5. Representasi Kurva Variabel Output Kesiapan

Sedangkan rangkuman variabel input beserta nilai operasional dan himpunan fuzzynya dapat dilihat pada tabel 3. Dari tabel tersebut tampak bahwa penelitian ini memiliki 21 variabel input, yang merupakan variabel operasional dari 4 indikator utama.

Tabel 3. Variabel Input

\begin{tabular}{|c|l|c|c|c|}
\hline \multirow{2}{*}{ ALIAS } & \multicolumn{1}{|c|}{ VARIABEL } & RENDAH & SEDANG & TINGGI \\
\cline { 2 - 4 } & & $0-1.5$ & $0.5-2.5$ & $1.5-3$ \\
\hline A1 & Jumlah Payung Hukum Yang Dihasilkan & $<3$ & $3-5$ & $>5$ \\
\hline A2 & Dukungan Dana Yang Diberikan & $<10 J T$ & $10-50 J T$ & $>50 J T$ \\
\hline A3 & Jumlah Kelompok Yang Terorganisir & $<3$ & $3-5$ & $>5$ \\
\hline A4 & Pelibatan Masyarakat dalam Forum Pengambilan Keputusan/Th & $<3 \mathrm{X}$ & $3-6 \mathrm{X}$ & $>6 \mathrm{X}$ \\
\hline B1 & Online & $<10$ & $10-30 \mathrm{OL}$ & $>30$ \\
\hline B2 & Jumlah Pengaduan/th & $>12$ & $6-12$ & $<6$ \\
\hline B3 & Jumlah Pengaduan Terselesaikan/th & $<6$ & $6-12$ & $>12$ \\
\hline B4 & Lama Waktu Penyelesaian/Kasus rata-rata/th & $>3$ & $1-3$ & $<1$ \\
\hline C1 & Jenis Blue Print/pelayanan publik & $<=1$ & $1-3$ & $>3$ \\
\hline C2 & SOP & $<10$ & $10-25$ & $>25$ \\
\hline C3 & Payung Hukum Keterbukaan Informasi & $<1$ & $1-5$ & $>5$ \\
\hline C4 & Persentase SKPD terbuka terhadap Informasi Utk Masyarakat & $<5$ & $5-25$ & $>25$ \\
\hline C5 & Jenis Media Yang Disediakan Untuk Mengakses Informasi Utk Masyarakat & $<5$ & $5-10$ & $>10$ \\
\hline C6 & Jenis Perencanaan & $<2$ & $2-3$ & $>3$ \\
\hline C7 & Mekanisme Perencanaan & $<2$ & $2-3$ & $>3$ \\
\hline D1 & Organisasi Keagamaan & $<5$ & $5-10$ & $>10$ \\
\hline D2 & Organisasi Seni dan Kebudayaan & $<5$ & $5-10$ & $>10$ \\
\hline D3 & Persentase Pertemuan antar organisasi keagamaan/th & $<2$ & $2-3$ & $>3$ \\
\hline D4 & Persentase Aktualisasi Kelompok Seni dan Budaya/th & $<2$ & $2-3$ & $>3$ \\
\hline D5 & Kelengkapan Unsur tata kelola sospol & $<2$ & $2-3$ & $>3$ \\
\hline D6 & Persentase potensi konflik/th & $>5$ & $2-5$ & $<2$ \\
\hline
\end{tabular}

\section{c. Penentuan Aturan (Rule IF...THEN)}

Dari data yang diperoleh dari narasumber, diperoleh 90 aturan yang diterjemahkan ke dalam bentuk IF-THEN. Sebagai contoh, IF Indikator A rendah AND Indikator B Rendah AND Indikator C Rendah AND Indikator D Rendah THEN Kesiapan Rendah. Secara prinsip basis aturan ini sangat mempengaruhi hasil akhir dari tingkat kesiapan yang akan diuji. Sekalipun demikian, aturan yang dibentuk adalah hasil dari diskusi dengan narasumber yang sahih. Jika aturan dilakukan melalui 
rekayasa matematika, semestinya terdapat lebih dari 100 kombinasi aturan. Dalam penelitian ini basis aturan didasarkan pada realitas dan buah pemikiran narasumber.

\section{d. Hasil Akhir}

Dengan menggunakan alat bantu Matlab R2017b dapat diketahui bahwa model Fuzzy Inference System Mamdani adalah seperti tampak pada gambar 6.

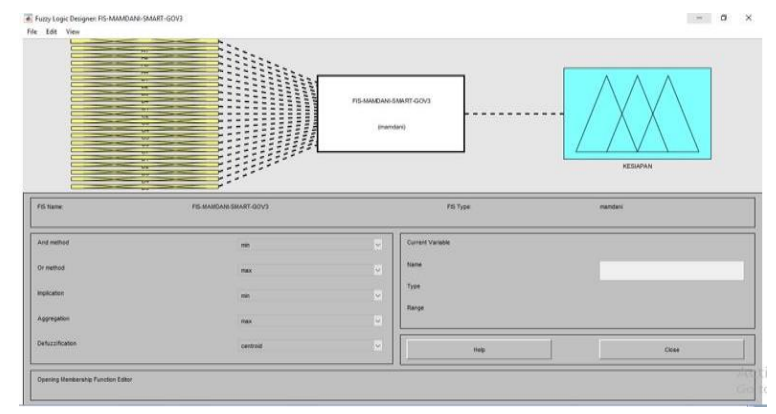

Gambar 6. Model FIS Mamdani Smart Governance

Sedangkan aturan sejumlah 90 dibuat melalui Rule Editor, seperti tampak pada gambar 7. di bawah ini.

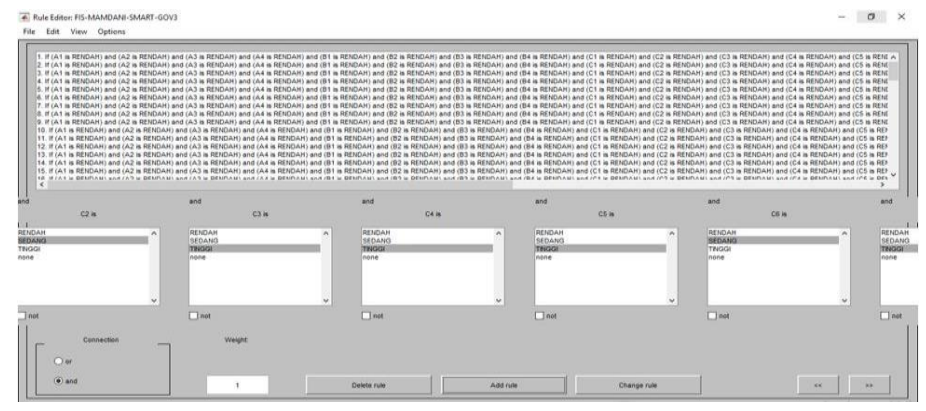

Gambar 7. Rule Yang Terbentuk Menggunakan Rule Editor

Narasumber kemudian menjawab realitas yang terjadi di lapangan sesuai dengan data dan fakta yang saat ini dimiliki. Dalam hal ini, pertanyaan terkait dengan 4 indikator yang telah dioperasionalkan ke dalam 21 variabel dengan rentang himpunan yang juga telah ditentukan. Tabel 4 merangkum kondisi riil yang hendak dihitung menggunakan metode FIS Mamdani dengan bantuan MATLAB R2016b.

Tabe 4. Kondisi Riil Berdasarkan Indikator Smart Governance

\begin{tabular}{|c|c|c|c|c|c|c|c|}
\hline ALIAS & VARIABEL & \begin{tabular}{|c|} 
RENDAH \\
$0-1.5$ \\
\end{tabular} & \begin{tabular}{|c|} 
SEDANG \\
$1-2$ \\
\end{tabular} & \begin{tabular}{|c|} 
TINGGI \\
$1.5-3$ \\
\end{tabular} & JAWAB & N.FUZZY & \begin{tabular}{|l|} 
Range \\
Fuzzy \\
\end{tabular} \\
\hline A1 & Jumlah Payung Hukum Yang Dihasilkan & $<3$ & $3-5$ & $>5$ & 10 Payung Hukum & TINGGI & 3 \\
\hline $\mathrm{A} 2$ & Dukungan Dana Yang Diberikan & $<10 \mathrm{JT}$ & $10-50 \mathrm{JT}$ & $>50 \mathrm{JT}$ & $75 \mathrm{JT}$ & TINGGI & 3 \\
\hline A3 & Jumlah Kelompok Yang Terorganisir & $<3$ & $3-5$ & $>5$ & 4 Organisasi & SEDANG & 2 \\
\hline A4 & $\begin{array}{l}\text { Pelibatan Masyarakat dalam Forum Pengambilan } \\
\text { Keputusan/Th }\end{array}$ & $<3 \mathrm{X}$ & $3-6 X$ & $>6 \mathrm{X}$ & 2X/TH & RENDAH & 1 \\
\hline B1 & Online & $<10$ & 10-30OL & $>30$ & 10 Situs Online di SKPD & SEDANG & 2 \\
\hline B2 & Jumlah Pengaduan/th & $>12$ & $6-12$ & $<6$ & $8 /$ th & RENDAH & 1 \\
\hline B3 & Jumlah Pengaduan Terselesaikan/th & $<6$ & $6-12$ & $>12$ & $5 /$ th & RENDAH & 1 \\
\hline B4 & Lama Waktu Penyelesaian/Kasus rata-rata /th & $>3$ & $1-3$ & $<1$ & 3-4 bulan & RENDAH & 1 \\
\hline $\mathrm{C} 1$ & Jenis Blue Print/pelayanan Publik & $<=1$ & $1-3$ & $>3$ & 2 blue print & SEDANG & 2 \\
\hline $\mathrm{C} 2$ & SOP & $<10$ & $10-25$ & $>25$ & $30 \mathrm{SOP}$ & TINGGI & 3 \\
\hline $\mathrm{C} 3$ & Payung Hukum Keterbukaan Informasi & $<1$ & $1-5$ & $>5$ & 2 payung hukum & SEDANG & 2 \\
\hline $\mathrm{C} 4$ & $\begin{array}{l}\text { Persentase SKPD Terbuka terhadap } \\
\text { Informasi Utk Masyarakat }\end{array}$ & $<5$ & $5-25$ & $>25$ & $40 \%$ & TINGGI & 3 \\
\hline $\mathrm{C} 5$ & $\begin{array}{l}\text { Jenis Media Yang Disediakan Untuk Mengakses } \\
\text { Informasi Utk Masyarakat }\end{array}$ & $<5$ & $5-10$ & $>10$ & 10 jenis media & SEDANG & 2 \\
\hline C6 & Jenis Perencanaan & $<2$ & $2-3$ & $>3$ & 10 jenis perencanaan & TINGGI & 3 \\
\hline $\mathrm{C} 7$ & Mekanisme Perencanaan & $<2$ & $2-3$ & $>3$ & 5 kali & TINGGI & 3 \\
\hline D1 & Organisasi Keagamaan & $<5$ & $5-10$ & $>10$ & 8 organisasi keagamaan & SEDANG & 2 \\
\hline D2 & Organisasi Seni dan Kebudayaan & $<5$ & $5-10$ & $>10$ & 1 organisasi seni & RENDAH & 1 \\
\hline
\end{tabular}




\begin{tabular}{|c|l|c|c|c|c|c|c|}
\hline D3 & $\begin{array}{l}\text { Persentase Pertemuan antar organisasi } \\
\text { keagamaan/th }\end{array}$ & $<2$ & $2-3$ & $>3$ & $2 \times /$ th & SEDANG & 2 \\
\hline D4 & $\begin{array}{l}\text { Persentase Aktualisasi Kelompok Seni dan } \\
\text { Budaya/th }\end{array}$ & $<2$ & $2-3$ & $>3$ & $1 \times /$ th & RENDAH & 1 \\
\hline D5 & Kelengkapan Unsur tata kelola sospol & $<2$ & $2-3$ & $>3$ & 5 unsur & TINGGI & 3 \\
\hline D6 & Persentase potensi konflik/th & $>5$ & $2-5$ & $<2$ & $2 /$ th & SEDANG & 2 \\
\hline
\end{tabular}

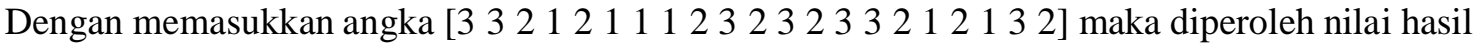
1.5. Hasil ini menggunakan metode defuzzyfikasi centroid. Hasil tampak pada gambar 8. Dengan melakukan uji beberapa kali menggunakan metode defuzzyfikasi yang berbeda, yaitu MOM, SOM dan LOM, hasil akhir yang diperoleh adalah sama, yaitu 1.5. Nilai angka 1.5 memberikan makna bahwa tingkat kesiapan Pemerintah Kota Pekalongan untuk mengimplementasikan Smart City dari perspektif Smart Governance berada pada tingkat sedang.

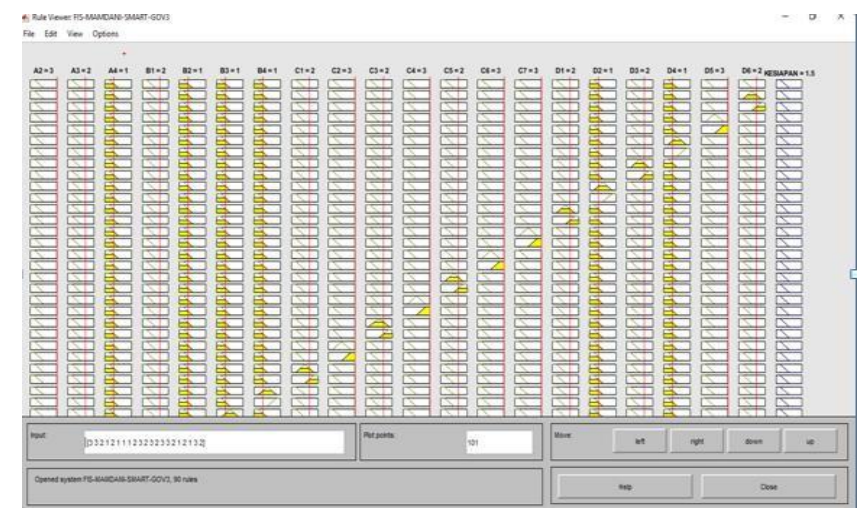

Gambar 8. Tingkat Kesiapan Penerapan Smart City Dalam Perspektif Smart Governance

\section{KESIMPULAN}

Pada akhirnya penelitian ini dapat memberikan beberapa kesimpulan atas hasil akhir yang diperoleh, sebagai berikut:

1) Indikator Smart Governance yang diturunkan ke dalam Indikator Operasional ditetapkan sebagai variabel input sebanyak 21 buah indikator. Ke-21 variabel input tersebut direpresentasikan menggunakan kurva bahu dalam rentang 0-3 dengan himpunan keanggotaan rendah, sedang dan tinggi

2) Dengan menggunakan fungsi implikasi Min dan defuzzifikasi centroid maka dapat dihasilkan Tingkat Kesiapan Kota Pekalongan menerapkan Smart City dalam perspektif Smart Governance adalah 1,5 atau dalam nilai linguistik fuzzy adalah Sedang.

\section{SARAN}

Berdasarkan paparan dan hasil penelitian yang telah dijelaskan maka diperlukan beberapa masukan yang dapat menjadi bahan untuk meningkatkan dan/atau menyempurnakan penelitian yang sudah dilakukan, antara lain:

1) Perspektif dapat diperluas tidak hanya dari sisi Smart Governance saja tetapi juga dari perspektif Smart Economy dan lain sebagainya

2) Basis Aturan dapat diperkaya dengan menggunakan kombinasi matematika

\section{UCAPAN TERIMA KASIH}

Penulis mengucapkan terima kasih kepada segenap jajaran Dinas Komunikasi dan Informasi (DinKominfo) Kota Pekalongan yang telah bersedia menjadi obyek penelitian dan memberikan narasumber- narasumber yang sangat kooperatif sehingga penelitian ini dapat terselesaikan dengan baik. Ucapan terimakasih juga kami sampaikan kepada LPPM Universitas Stikubank yang telah memberikan"dukungan financial" terhadap penelitian ini.

\section{DAFTAR PUSTAKA}

[1] G. Cristian and M. Roscia, "Definition methodology for the smart cities model," Energy, vol. 47, pp. 326-332, 2012. 
[2] T. Nam and T. A. Pardo, "Conceptualizing Smart City with Dimensions of Technology, People , and Institutions," in The Proceedings of the 12th Annual International Conference on Digital Government Research, 2011, pp. 282-291.

[3] R. E. Hall, J. Braverman, J. Taylor, and H. Todosow, "The Vision of A Smart City." 2nd International Life Extention Technology Workshop; Paris France, Paris, Perancis, pp. 1-6, 2000.

[4] N. Komninos, C. Bratsas, C. Kakderi, and P. Tsarchopoulos, "Smart City Ontologies: Improving the effectiveness of smart city applications," J. Smart Cities, vol. 1, no. 1, pp. 31-46, 2015.

[5] [M. A. Shokouhi, S. N. N. Rokni, H. Alizadeh, and A. Ahmadi, "Evaluation of Smart City Criteria in Ahvaz City, Iran PhD Student in Geography and Urban Planning, Shahid Chamran University of Ahvaz, Iran 4PhD Student in," Int. J. Archit. Eng. Urban Plan, vol. 26, no. 2, pp. 141-149, 2016.

[6] R. Giffinger, C. Fertner, H. Kramar, R. Kalasek, N. Pichler-Milanović, and E. Meijers, "Smart cities Ranking of European medium-sized cities," Centre of Regional Science, Vienna UT, German, 2007.

[7] A. Caragliu, C. Del Bo, P. Nijkamp, A. Caragliu, C. Del Bo, and P. Nijkamp, "Smart Cities in Europe," J. Urban Technol., no. October 2012, pp. 37-41, 2011.

[8] S. Allwinkle and P. Cruickshank, "Creating Smart-er Cities: An Overview Creating Smart-er Cities : An Overview," J. Urban Technol., no. January 2014, pp. 37-41, 2011.

[9] F. Mosannenzadeh and D. Vettorato, "Defining Smart City: A Conceptual Framework Based On Keyword Analysis," TeMA J. L. Use, Mobil. Environ., no. SMART CITY PLANNING FOR ENERGY, TRANSPORTATION AND SUSTAINABILITY OF THE URBAN SYSTEM, pp. 683-694, 2014.

[10] Retnowati, "Partisipasi Warga Melalui Pusat Informasi Warga ( Community Dalam Perspektif Keterbukaan Informasi Publik Di era OGI ( Open Government Indonesia ) Studi Pada Kota Pekalongan," $2017 . \quad$ [Online]. Available: https://www.academia.edu/34688226/Partisipasi_Warga_Melalui_Pusat_Informasi.

[11] A. Gaeta, M. Gaeta, V. Loia, and M. Z. Reformat, "Collective Awareness in Smart City with Fuzzy Cognitive Maps and Fuzzy sets," in FUZZ-IEEE, 2016, pp. 1554-1561.

[12] M. L. De Maio, "Fuzzy utility models : possible applications in evacuation conditions in smart cities," WIT Trans. Ecol. Environ., vol. 173, pp. 779-790, 2013.

[13] P. Kaltenrieder, C.- Bern, E. Portmann, M. Finger, and S. D. Onofrio, "Applying the Fuzzy Analytical Hierarchy Process in Cognitive Cities," in ICEGOV'14 Proceedings of the 8th International Conference on Theory and Practice of Electronic Governance, 2014, pp. 259-262.

[14] M. I. Perangin-angin, Khairul, and Andysah Putera Utama Siahaan, "Fuzzy Logic Concept in Technology, Society, and Economy Areas in Predicting Smart City Fuzzy Logic Concept in Technology , Society, and Economy Areas in," Int. J. Recent Trends Eng. Res., vol. 2, no. December, pp. 176-181, 2016.

[15] S. Kusumadewi and H. Purnomo, Aplikasi Logika Fuzzy Untuk Pendukung Keputusan, 1st ed. Yogyakarta: Graha Ilmu, 2004.

[16] Retnowati, "Optimalisasi Jumlah Produksi Batik Cap Dengan Menggunakan Metode Fuzzy Mamdani," J.Litbang Kota Pekalongan, vol. 3, no. 1, pp. 1-11, 2010.

[17] F. Camastra et al., "Expert Systems with Applications A fuzzy decision system for genetically modified plant environmental risk assessment using Mamdani inference," Expert Syst. Appl., no. October, 2014.

[18] A. Kaur and A. Kaur, "Comparison of Mamdani-Type and Sugeno-Type Fuzzy Inference Systems for Air Conditioning System," no. 2, pp. 323-325, 2012.

[19] H. Zaher, A. E. Kandil, and R. Fahmy, "SCIENCEDOMAIN international Comparison of Mamdani and Sugeno Fuzzy Inference Systems for Prediction ( With Application to Prices of Fund in Egypt )," vol. 4, no. 21, pp. 3014-3022, 2014.

[20] M. Asadi, "Journal of Rock Mechanics and Geotechnical Engineering Optimized Mamdani fuzzy models for predicting the strength of intact rocks and anisotropic rock masses," J. Rock Mech. Geotech. Eng., vol. 8, no. 2, pp. 218-224, 2016.

[21] N. Alavi, "Quality determination of Mozafati dates using Mamdani fuzzy inference system," $J$. Saudi Soc. Agric. Sci., vol. 12, no. 2, pp. 137-142, 2013. 
[22] J. Shah, Exploratory Research on Smart Cities: Theory, Policy and Practice. India, 2017.

[23] S. Joss, M. Cook, and Y. Dayot, "Smart Cities : Towards a New Citizenship Regime? A Discourse Analysis of the British Smart City Standard Smart Cities: Towards a New Citizenship Regime? A Discourse Analysis of the British Smart City Standard," J. Urban Technol., vol. 0, no. 0, pp. 1-21, 2017.

[24] Yoshihito Yoshikawa, A. Sato, S. Hirasawa, M. Takahashi, and M. Yamamoto, "Hitachi's Vision of the Smart City," Hitachi Review, vol. 61, no. 3. Japan, pp. 111-118, 2012.

[25] B. Cohen, "The Top 10 Smart Cities On The Planet _ Where business and design collide," Fast Company, 2011. [Online]. Available: http://www.fastcoexist.com/1679127/the-top-10-smartcities-on-the-planet . [Accessed: 04-Oct-2017].

[26] John W. Creswell, Research Design Qualitative, QUantitative, and Mixed Methods Approaches. United States of America: Sage Publications, Inc., 2014.

[27] S. N. Hesse-Biber, Mixed Methods Research: Merging Theory with Practice. The Guildford Press, 2010.

[28] S. L. Schensul, J. J. Schensul, and Margaret D. LeCompte, Initiating Ethnographic Research: A Mixed Methods Approach. UK: Rowman \& LittleField Publishers, INC., 2013. 